E3S Web of Conferences 1, 20007 (2013)

DOI: $10.1051 / \mathrm{e} 3$ sconf/20130120007

(c) Owned by the authors, published by EDP Sciences, 2013

\title{
Ambient air pollution by mercury species at the urban station in Zabrze, Southern Poland
}

\author{
$\underline{\text { H. Pyta }}^{1}$ \\ ${ }^{1}$ Institute of Environmental Engineering, Polish Academy of Sciences, 41-819 Zabrze, ul. Curie-Skłodowskiej 34, \\ POLAND,pyta@ipis.zabrze.pl
}

\begin{abstract}
The study presents the initial results of semi-continuous measurements of atmospheric mercury species $\left(\mathrm{Hg}^{0}, \mathrm{Hg}^{2+}\right.$ and particle mercury $\mathrm{Hg}_{\mathrm{p}}$ bound with PM2.5) in Zabrze obtained between January and December 2011. Zabrze is a city (190,000 inhabitants) within Upper Silesia Agglomeration, the most urbanised and industrialised part of Poland. Ambient air was sampled from the roof of the two-storey building of Institute of Environmental Engineering of the Polish Academy of Sciences (residential area). The measurements were performed using a Tekran 2537B mercury analyzer together with a 1130 Speciation Unit and a $1135 \mathrm{Hg}_{\mathrm{p}}$ Unit. $\mathrm{Hg}^{2+}$ is captured in the unit 1130 (KCl-coated denuder), while $\mathrm{Hg}_{\mathrm{p}}$ is trapped onto a regenerable filter inside the module $1135 . \mathrm{Hg}^{0}$ remaining in the air stream is then directed into the $2537 \mathrm{~B}$ mercury analyzer and detected using cold vapour atomic fluorescence spectrometry. The concentration of $\mathrm{Hg}^{0}$ (5-minutes data) was from 1.5 to $67.5 \mathrm{ng} \mathrm{m}^{-3}$, with $3.3 \mathrm{ng} \mathrm{m}^{-3}$ as a mean value. $\mathrm{Hg}^{2+}$ concentration (1-hour data) varied from $<1$ to $763 \mathrm{pg} \mathrm{m}^{-3}$, at arithmetic mean of $25 \mathrm{pg} \mathrm{m}^{-3}$. The concentration of $\mathrm{Hg}_{\mathrm{p}}$ (1-hour data) ranged from $<1 \mathrm{pg} \mathrm{m}^{-3}$ to $4.8 \mathrm{ng} \mathrm{m}^{-3}$, on average $52 \mathrm{pg} \mathrm{m}^{-3}$. While the concentration of $\mathrm{Hg}^{0}$ did not diverge generally from the levels observed in urban areas of Western Europe and Northern America, the concentrations of two remaining $\mathrm{Hg}$ forms were higher. Their concentrations were higher in winter than in summer unlike the concentration of $\mathrm{Hg}^{0}$.
\end{abstract}

Key words: air pollution, mercury speciation, urban background

\section{Introduction}

Mercury is released to the air mainly in the form of gaseous elemental mercury $\mathrm{Hg}^{0}$ with minor amounts of gaseous divalent mercury $\mathrm{Hg}^{2+}$ and particle-bound mercury $\mathrm{Hg}_{\mathrm{p}}$ (UNEP, 2008). The dominant form of atmospheric mercury $\mathrm{Hg}^{0}$ is relatively inert and has a low aqueous solubility. These properties are the major reasons for its long atmospheric lifetime of the order of 1 yr (Slemr et al., 1985). Deposition of $\mathrm{Hg}^{0}$ is preceded by an oxidation to divalent form or conversion to particle-bound mercury (Schroeder and Munthe, 1998). Divalent mercury compounds are commonly referred to as reactive gaseous mercury (RGM) and they constitute a small fraction of gas phase mercury (3\%; Bullock, 2000). RGM is believed to include primarily $\mathrm{HgCl}_{2}$, as well as $\mathrm{HgO}, \mathrm{Hg}(\mathrm{OH})_{2}, \mathrm{HgSO}_{4}, \mathrm{HgS}$ and several organic derivatives of mercury (Bullock, 2000). $\mathrm{HgCl}_{2}$ is highly soluble in water and may be efficiently removed by precipitation. Other mercury salts are insoluble and occur mostly as associated with particulate matter. Particle-bound mercury in the air is a result of direct emission, adsorption of gaseous mercury on aerosols and dissolution of $\mathrm{Hg}$ compounds in wetted aerosols. RGM and $\mathrm{Hg}_{\mathrm{p}}$ are present in the atmosphere at a concentration three orders of magnitude less than $\mathrm{Hg}^{0}$ but they have much shorter atmospheric lifetime, from several days to a few weeks (Lin and Pehkonen, 1999). $\mathrm{Hg}^{0}$ is considered global pollutant due to its long lifetime whereas RGM and $\mathrm{Hg}_{\mathrm{p}}$ are deposited only locally or regionally (UNEP 2008).

Measurements of atmospheric mercury species have been made in different parts of the world, but significant gaps in description of mercury transport and chemical conversion still exist, particularly in urban environment. In anthropogenically impacted environments mercury speciation depends on releases from specific sources and on oxidation of $\mathrm{Hg}^{0}$ to $\mathrm{Hg}^{2+}$. It is not fully understood which anthropogenic oxidants work and how they work (Lyman and Gustin, 2009).

Poland belongs to Europe's highest mercury emitters (Pacyna et al., 2006). The total amount of $\mathrm{Hg}$ emitted by the anthropogenic sources in Poland in 2003 was 20.2 t. Fuel combustion for heat and power 
generation, together with cement production were the most meaningful sources, with respectively: $57 \%$ and $27 \%$ share in the total anthropogenic $\mathrm{Hg}$ emission. Emission from metallurgy contributed $10 \%$, from chlorine production $5 \%$ and only $1 \%$ from waste incineration (Hlawiczka and Fudala, 2008). Based on own inventory data for the year 2006, mercury emission in the Upper Silesia Agglomeration, the most heavily urbanised and industrialised part of Poland with population of over 3.5 million inhabitants, was estimated on the level of $1.1 \mathrm{t}$. About $83 \%$ of this load originated from combustion of hard coal in power and heat generation, the remaining $17 \%$ from iron and steel production and from cokemaking.

The study presents the results of the $1^{\text {st }}$ year monitoring of mercury species at the urban background station in Zabrze. Zabrze is a city (190,000 inhabitants) in Upper Silesia Agglomeration, in its western part which is distinguished by old industrial and municipal infrastructure. Zabrze has the least developed heat supply network in the entire agglomeration, a coal fired power plant and industrial boiler houses as well as a coking plant within the city limits. Seasonal and diurnal variability of mercury concentration and the relations between mercury species and meteorological conditions were investigated.

\section{Materials and Methods}

The measurement station is located in the residential district, within the Institute of Environmental Engineering (IEE). Sampling point is situated about 14 $\mathrm{m}$ above the ground and $1.7 \mathrm{~m}$ above the roof of 2 -storey IEE building. There is also an automatic station of air quality monitoring located approximately $70 \mathrm{~m}$ from the IEE building, which made available hourly data on concentrations of co-pollutants (PM2.5, $\left.\mathrm{PM} 10, \mathrm{SO}_{2}, \mathrm{NO}_{\mathrm{x}}, \mathrm{CO}, \mathrm{O}_{3}\right)$ and some meteorological parameters (air temperature, wind direction and wind speed, humidity, precipitation). Mercury species $\left(\mathrm{Hg}^{0}\right.$, RGM, $\mathrm{Hg}_{\mathrm{p}}$ bound with PM2.5) concentrations were measured continuously between January and December 2011.

The measurements were performed using a Tekran 2537B/1130/1135, an automated Hg speciation system, which is based on the amalgamation of mercury onto a gold cartridge followed by thermal desorption and analysis by cold vapour atomic fluorescence spectrometry (CVAFS). Coarse particles were removed from the air stream at the first (impactor on the inlet). Then RGM was selectively captured by the KCl-coated quartz annular denuder in the 1130 speciation unit. Coarse particles can deactivate the denuder (Landis et al., 2002). Then $\mathrm{Hg}_{\mathrm{p}}$ was subsequently separated onto the regenerable quartz fibre filter which is located within the unit $1135 . \mathrm{Hg}^{0}$ remaining in the air stream was then directed into the main module, the mercury analyzer 2537B. $\mathrm{Hg}^{0}$ was analysed every $5 \mathrm{~min}$. Dual cartridge design allows alternate $\mathrm{Hg}^{0}$ sampling and desorption, resulting in continuous measurements. The speciation units were operated on a $2 \mathrm{~h}$ cycle, with $1 \mathrm{~h}$ sampling and preconcentration period followed by $1 \mathrm{~h}$ period of desorption and analysis. After each sampling period, the 1130 and 1135 modules were flushed with $\mathrm{Hg}$-free air during the next 1 hour. RGM and $\mathrm{Hg}_{\mathrm{p}}$ were sequentially thermodesorbed. Regenerable particulate filter was heated at the first and then the denuder was heated. Liberated mercury vapours were sequentially analysed as $\mathrm{Hg}^{0}$.

The denuder, particulate assembly and sample train glassware were exchanged every month. The Tekran 2537B was calibrated daily using an internal $\mathrm{Hg}^{0}$ permeation tube. Autocalibration was checked by periodic manual injections of external standard with using of a Tekran 2505 calibration unit. The precision of the Tekran $2537 \mathrm{~B}$ is $2 \%$ and the manufacturer detection limit for $\mathrm{Hg}^{0}$ is $<0.1 \mathrm{ng} \mathrm{m}^{-3}$ (Tekran, 2008). The precision of the Tekran 1130 and 1135 modules are not known. There are no available standards which can be used to test the precisions of these two modules (Liu et al., 2010). Field comparisons of manual and automated (Tekran 1130) denuders showed a good agreement.

\section{Results and Discussion}

Descriptive statistics for 1-hour concentrations of $\mathrm{Hg}$ species and PM2.5 as well as the air temperature are presented in Table 1. Summer denotes non-heating season (April - September), winter (heating season) comprises the remaining 6 months.

On average, the atmospheric $\mathrm{Hg}$ apportioned as follows: $\mathrm{Hg}^{0}(98.7 \%)>\mathrm{Hg}_{\mathrm{p}}(0.7 \%)>\mathrm{RGM}(0.6 \%) . \mathrm{Hg}^{0}$ concentrations ranged from 1.6 to $40.5 \mathrm{ng} \mathrm{m}^{-3}$ for 1 -hour data and from 1.5 to $67.5 \mathrm{ng} \mathrm{m}^{-3}$ for 5-minute data. Mean annual concentration of $\mathrm{Hg}^{0}\left(3.3 \mathrm{ng} \mathrm{m}^{-3}\right)$ was two times higher than the background level for the Northern Hemisphere of $1.5 \pm 0.2 \mathrm{ng} \mathrm{m}^{-3}$ (Lindberg et al., 2007). Much higher variability in concentration was observed for $\mathrm{RGM}$ and $\mathrm{Hg}_{\mathrm{p}}$ (1-hour data). RGM concentration varied from $<1$ to $763 \mathrm{pg} \mathrm{m}^{-3}$, at arithmetic mean of $25 \mathrm{pg} \mathrm{m}^{-3}$. The concentration of $\mathrm{Hg}_{\mathrm{p}}$ ranged from $<1 \mathrm{pg}$ $\mathrm{m}^{-3}$ to $4.8 \mathrm{ng} \mathrm{m}^{-3}$, on average $52 \mathrm{pg} \mathrm{m}^{-3}$. High variation coefficient proves the presence of $\mathrm{RGM}$ and $\mathrm{Hg}_{\mathrm{p}}$ emission sources in a direct vicinity of the measurement station. Mean concentrations of RGM and $\mathrm{Hg}_{p}$ were several times higher than the background concentrations $\left(<1.0-5.0 \mathrm{pg} \mathrm{m}^{-3}\right.$, Jaffe et al., 2005).

A clear seasonal differentiation in the concentrations of all three $\mathrm{Hg}$ species was noted. The average RGM concentration in winter season was about $36 \%$ higher than in summer. Mean $\mathrm{Hg}_{\mathrm{p}}$ level was 3 times higher in winter than in summer, proportionally to the seasonal variation of PM2.5 concentrations.

Higher concentrations of $\mathrm{Hg}_{\mathrm{p}}$ and $\mathrm{RGM}$ in winter season were due to higher $\mathrm{Hg}$ emission from the local cookery (Fig. 1, advection from the ENE sector) and from coal combustion for heating purposes (the ESE sector - municipal buildings with individual furnaces and the WSW sector - district heating plant). Lower concentrations of $\mathrm{Hg}^{0}$ in winter were caused by the sampling point elevation. In summer season, a high 
situated air intake enabled to record the peak concentrations of $\mathrm{Hg}^{0}$ originating from the high and distant sources of regional scale. In winter season, regional transport of $\mathrm{Hg}^{0}$ was significantly restricted by the thermal inversion layers. They disrupted typical diurnal distribution of $\mathrm{Hg}^{0}$ concentrations with maximum at nighttime. Such distribution was observed only in summer season (Fig. 2). The diurnal distribution of RGM concentrations exhibited an increase about midday. This proves the activity of secondary RGM sources (oxidation of $\mathrm{Hg}^{0}$ ). Higher $\mathrm{Hg}_{\mathrm{p}}$ concentrations were observed at nighttime as a result of night weather conditions, unfavourable to the dispersion of pollutants as well as the more efficient sorption of gaseous mercury on aerosol particles.

Table 1. Statistical summary of $1 \mathrm{~h}$ mercury and PM2.5 concentrations and the air temperature in summer and winter season and during the whole year.

\begin{tabular}{|c|c|c|c|c|}
\hline Parameter & Statistic & Summer & Winter & Year \\
\hline \multirow{4}{*}{$\begin{array}{c}\mathrm{Hg}^{0} \\
{\left[\mathrm{ngm}^{-3}\right]}\end{array}$} & Mean & 3.6 & 2.9 & 3.3 \\
\hline & Stand.Dev. & 2.0 & 1.3 & 1.7 \\
\hline & Median & 3.1 & 2.5 & 2.8 \\
\hline & Max & 40.5 & 18.5 & 40.5 \\
\hline \multirow{4}{*}{$\begin{array}{c}\text { RGM } \\
{\left[\mathrm{pgm}^{-3}\right]}\end{array}$} & Mean & 21.2 & 28.7 & 24.6 \\
\hline & Stand.Dev. & 31.8 & 39.0 & 35.5 \\
\hline & Median & 11.5 & 19.3 & 14.9 \\
\hline & Max & 380.3 & 763.3 & 763.3 \\
\hline \multirow{4}{*}{$\begin{array}{c}\mathrm{Hg}_{\mathrm{p}} \\
{\left[\mathrm{pgm}^{-3}\right]}\end{array}$} & Mean & 26.5 & 81.1 & 51.5 \\
\hline & Stand.Dev. & 42.7 & 176.2 & 126.3 \\
\hline & Median & 15.0 & 44.0 & 24.5 \\
\hline & Max & 670.8 & 4786.6 & 4786.6 \\
\hline \multirow{4}{*}{$\begin{array}{c}\text { PM2.5 } \\
{\left[\mathrm{mgm}^{-3}\right]}\end{array}$} & Mean & 19.3 & 56.7 & 37.7 \\
\hline & Stand.Dev. & 17.3 & 72.6 & 55.5 \\
\hline & Median & 15.0 & 37.0 & 21.0 \\
\hline & Max & 174.0 & 929.0 & 929.0 \\
\hline \multirow{3}{*}{$\begin{array}{c}\text { Temp. } \\
{\left[{ }^{\circ} \mathrm{C}\right]}\end{array}$} & Mean & +16.5 & +3.4 & +10.0 \\
\hline & Min & -1.2 & -13.3 & -13.3 \\
\hline & Max & +33.6 & +24.7 & +33.6 \\
\hline
\end{tabular}

\section{Conclusion}

One-year measurement series of gaseous elemental, reactive and particulate mercury concentrations, conducted at the urban station in Zabrze was analysed. A comparison between the levels of $\mathrm{Hg}$ in this study and other experiments suggests a significant urban and industrial influence. The distribution of the concentrations of all $\mathrm{Hg}$ species, especially $\mathrm{Hg}_{\mathrm{p}}$ and RGM, exhibited elevated values and large fluctuations. Strong temporal variability of RGM and $\mathrm{Hg}_{\mathrm{p}}$ was evidenced by the greater standard deviations as compared to the respective mean values. The distribution of $\mathrm{Hg}^{0}$
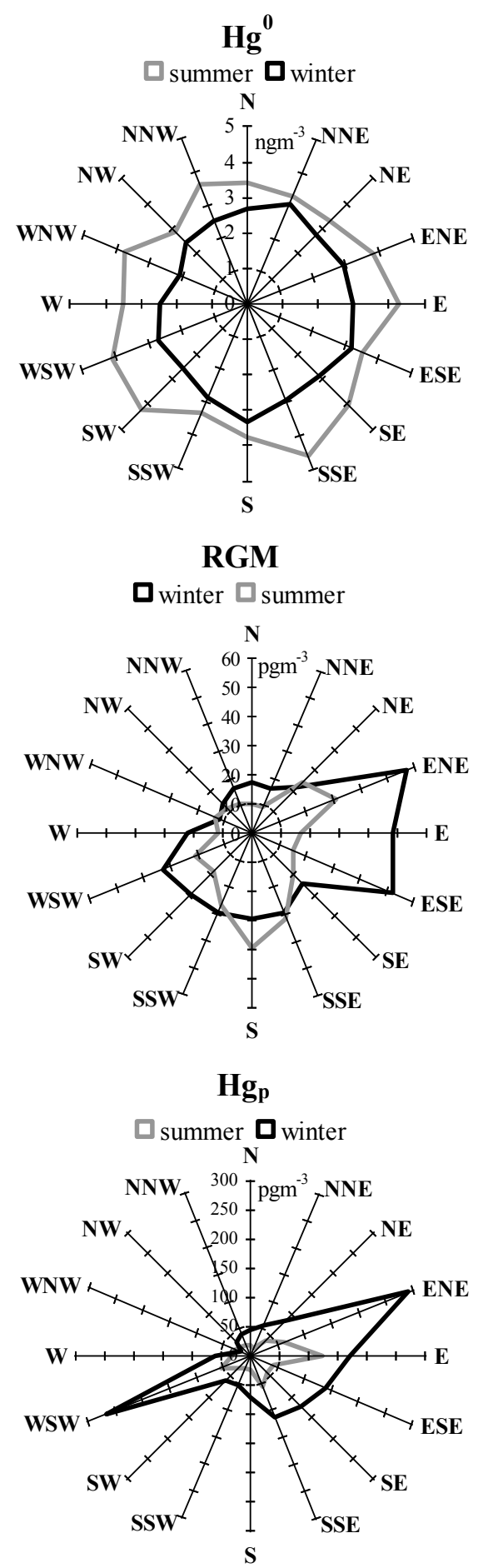

Fig.1. Pollution roses for $\mathrm{Hg}$ species in summer and winter season.

concentrations was considerably more stable. This suggests that both local and regional emission sources as well as the seasonal meteorological conditions were important factors affecting $\mathrm{Hg}$ variability.

A clear seasonality in $\mathrm{Hg}$ speciation was observed with $\mathrm{RGM}$ and $\mathrm{Hg}_{\mathrm{p}}$ concentrations significantly higher in winter season, while $\mathrm{Hg}^{0}$ concentrations were higher in summer season. All three Hg species also exhibited clear diurnal trends. Higher RGM concentrations were observed during the day than at night. Distribution of both $\mathrm{Hg}^{0}$ and $\mathrm{Hg}_{\mathrm{p}}$ concentrations exhibited a similar diurnal pattern being higher at night. 


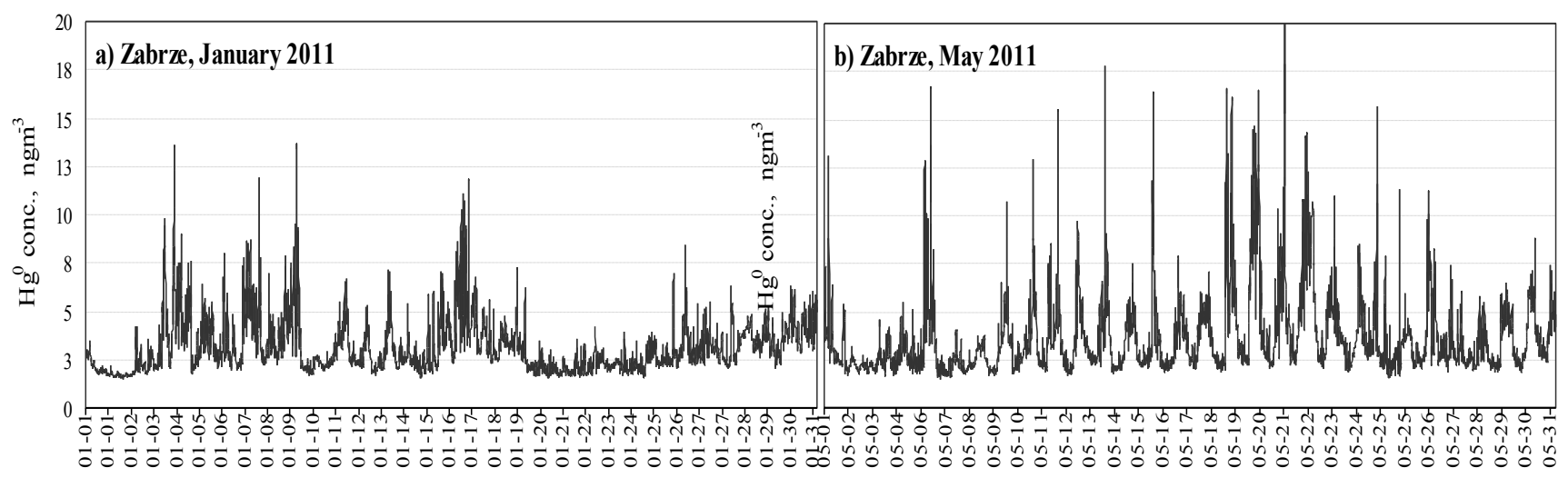

Fig. 2. Time series of $1 \mathrm{~h} \mathrm{Hg}^{0}$ concentrations for the selected month in (a) winter and (b) summer season.

\section{References}

Bullock JrOR. Current methods and research strategies for modelling atmospheric mercury. Fuel Processing Technology 2000; 459:65-66.

Hlawiczka S, Fudala J. Assessment of Atmospheric Mercury Emission Reduction Measures Relevant for Application in Poland. Environmental Engineering Science 2008; 25(2):163-172.

Jaffe D, Prestbo E, Swartzendruber P, Weiss-Penzias P, Kato S, Takami A, Hatakeyeyama S, Kajii Y. Export of atmospheric emissions from Asia, Atmospheric Environment 2005; 39(7):3029-3038.

Landis MS; Stevens RK; Schaedlich F, Prestbo E. Development and characterization of an annular denuder methodology for the measurement of divalent inorganic reactive gaseous mercury in ambient air. Environmental Science and Technology 2002; 36:3000-3009.

Lin CJ, Pehkonen SO. The chemistry of atmospheric mercury: a review. Atmospheric Environment 1999; 33:2067-2079.

Lindberg SE, Bullock R, Ebinghaus R, Engstrom D, Feng X, Fitzgerald W, Pirrone N, Prestbo E, Seigneur C. A Synthesis of Progress and Uncertainties in Attributing the Sources of Mercury in Deposition. Ambio 2007;
36(1):19-32.

Liu B, Keeler GJ, Dvonch JT, Barres JA, Lynam MM, Marsik FJ, Morgan JT. Urban-rural differences in atmospheric mercury speciation. Atmospheric Environment 2010; 44:2013-2023.

Lyman SN, Gustin MS. Determinants of atmospheric mercury concentrations in Reno, Nevada, U.S.A.. Science and the Total Environment 2009; 408:431-438.

Pacyna JM, Pacyna EG, Fudala J, Strzelecka-Jastrzab E, Hlawiczka S, Panasiuk D. Mercury emissions to the atmosphere from anthropogenic sources in Europe in 2000 and their scenarios until 2020. Science and the Total Environment 2006; 370:147-156.

Schroeder WH, Munthe J. Atmospheric mercury - an overview. Atmospheric Environment 1998; 32(5):809-822.

Slemr F, Schuster G., Seiler W. Distribution, speciation and budget of atmospheric mercury. Journal of Atmospheric Chemistry 1985; 3:407-434.

Tekran Instr. Co. (2008). Model 2537B Ambient Mercury Vapor Analyzer, User Manual, Toronto, Canada.

UNEP (2008). Technical Background Report to the Global Atmospheric Mercury Assessment; AMAP/UNEP Chemicals Branch 2008. 